\title{
Does compaction degree and particle size influence bromatological composition and mycotoxin levels in corn silage?
}

A densidade da compactação e o tamanho da partícula influenciam na composição bromatológica e nos níveis de micotoxinas em silagens de milho?

E. A. de Toledo ${ }^{1}$; S. F. N. Pertile ${ }^{1 *}$; J. Sifuentes dos Santos 2 ; J. V. P. Barreto ${ }^{1}$; G. Banchero $^{3}$; M. D. Dos Santos ${ }^{4}$; R. L. Venancio ${ }^{2}$; E. L. A. Ribeiro ${ }^{5}$; M. Zamboti ${ }^{1}$; M. Zundt ${ }^{6}$; F. C. de A. Rego ${ }^{1}$

${ }^{1}$ Programa de Mestrado em Saúde e Produção de Animal, Universidade Pitágoras Unopar, 86702-670, Arapongas $P R$, Brasil.

${ }_{2}^{2}$ Programa de Mestrado em Ciência e Tecnologia de Leite e Derivados, Universidade Pitágoras Unopar, 86040-141, Londrina - PR, Brasil.

${ }^{3}$ Beef and Wool Program, Instituto Nacional de Investigación Agropecuaria (INIA), Colonia, Uruguay.

${ }^{4}$ Programa de Mestrado e Doutorado em Biociência Animal, Universidade de Cuiabá (UNIC), 78015-480, Cuiabá MT, Brasil,

${ }^{5}$ Departamento de Zootecnia. Universidade Estadual de Londrina (UEL), 86057970, Londrina - PR, Brasil.

${ }^{6}$ Programa de Pós-graduação em Ciência Animal, Universidade do Oeste Paulista, 19050-920, Presidente PrudenteSP, Brasil.

*s.pertile@zootecnista.com.br

(Recebido em 08 de maio de 2020; aceito em 13 de julho de 2020)

The objective of this study was to evaluate the effects of compaction degree and particle size on the presence of mycotoxins and the bromatological composition of corn silages. Samples from 47 silos with forage corn silage were collected from the northern region of Paraná State, Brazil. The bromatological composition and concentration of mycotoxin in silages were analyzed according to both the compaction degree $\left(600 \mathrm{~kg} . \mathrm{m}^{-3}\right.$ and $700 \mathrm{~kg} . \mathrm{m}^{-3}$ ) and particle size. Mycotoxins were detected using enzyme-linked immunosorbent assay, and test results were considered positive when the mycotoxin concentration was above the detection limit of 100 $\mu \mathrm{g} . \mathrm{kg}^{-1}$ for deoxynivalenol, $2.5 \mu \mathrm{g} . \mathrm{kg}^{-1}$ for aflatoxin, $5 \mu \mathrm{g} . \mathrm{kg}^{-1}$ for zearalenone, and $200 \mu \mathrm{g} . \mathrm{kg}^{-1}$ for fumonisin. Silages with $600 \mathrm{~kg} \cdot \mathrm{m}^{-3}$ compaction degree had higher initial and final $\mathrm{pH}$ than silages with a higher compaction degree. Silage with a mean particle size less than or equal to $14.56 \mathrm{~mm}$ had $12 \%$ higher dry matter content than silage with a mean particle size more than $14.56 \mathrm{~mm}$. There was no effect of the compaction degree or particle size on the concentration of mycotoxin, and $83 \%$ of the analyzed samples had contamination above the detection limits according to at least one of the studied mycotoxins. Silages with smaller average particle sizes had higher dry matter content. Thus, the degree of compaction and particle size did not affect the presence of mycotoxins in corn silage.

Keywords: silage, secondary fungi metabolite, forage quality.

O objetivo do presente estudo foi avaliar os efeitos da densidade de compactação e tamanho de partícula na presença de micotoxinas e composição bromatológica de silagens de milho. Amostras de 47 silos contendo silagem de milho foram coletadas da região Norte do Estado do Paraná, Brasil. A composição bromatológica e os níveis de micotoxinas foram analisados de acordo com a densidade de compactação $\left(600 \mathrm{~kg} . \mathrm{m}^{-3}\right.$ and 700 $\mathrm{kg} . \mathrm{m}^{-3}$ ) e o tamanho de partícula. Micotoxinas foram avaliadas utilizando imunoensaio imunoenzimático, e os resultados foram avaliados considerando os seguintes limites de detecção: $100 \mu \mathrm{gg}_{\mathrm{kg}}{ }^{-1}$ para desoxinivalenol, $2,5 \mu \mathrm{g} . \mathrm{kg}^{-1}$ para aflatoxina, $5 \mu \mathrm{g} \cdot \mathrm{kg}^{-1}$ para zearalenona e $200 \mu \mathrm{g} . \mathrm{kg}^{-1}$ para fumonisina. Silagens com densidade de compactação de $600 \mathrm{~kg} \cdot \mathrm{m}^{-3}$ apresentaram maior $\mathrm{pH}$ inicial e final que as silagens com maior densidade de compactação. Silagens com tamanho de partícula inferior ou igual a 14,56 mm apresentaram 12\% maior conteúdo de massa seca que as silagens com tamanho de particula maior que 14,56 mm. Não houve efeito da densidade de compactação ou tamanho de partícula nos níveis de micotoxinas, e $83 \%$ das amostras analisadas apresentaram contaminação acima dos limites de detecção para ao menos uma das micotoxinas estudadas. Silagens com menor tamanho de partícula apresentaram maior conteúdo de massa 
seca. Assim, a densidade de compactação e o tamanho de partícula não influenciaram a presença de micotoxinas em silagem de milho.

Palavras-chave: silagem, metabólitos secundários fúngicos, qualidade de silagem.

\section{INTRODUCTION}

Corn (Zea mays) is one of the most planted forage crops both in Brazil and globally for silage production. Silage is obtained by fermentation under anaerobic conditions and, consequently, from spontaneous lactic acid production, leading to material preservation as the final $\mathrm{pH}$ is unfavorable for the growth of deteriorating microorganisms [1]. The final quality of corn silage is dependent on several factors, such as the nutritional value of the forage, how the silage is processed, opening of the silo, and mechanism by which it is supplied to animals.

The degree of compaction of the silo and the average particle size of the silage can determine the final quality of the silage. Compaction is carried out to eliminate the amount of air, and consequently oxygen, as much as possible to allow anaerobic fermentation. The size of the silage particles influences the removal of air and, consequently, the compaction of the silage [2]. In addition, toxicogenic fungi can contaminate corn during the planting, harvest, and storage periods. The three main fungal genera, which are mycotoxin producers and found in animal and human feeds, are Aspergillus spp., Penicillium spp., and Fusarium spp. Numerous fungal species belonging to these genera produce mycotoxin secondary metabolites such as aflatoxins, ochratoxins, trichothecenes (deoxynivalenol, nivalenol, T-2 toxin, among others), zearalenone (ZEA), fumonisins, and several other mycotoxins that are considered minor or emerging mycotoxins [3].

Mycotoxins can cause metabolic disorders and diseases in animals [4] and humans [5]. In animals, the consumption of mycotoxins can cause acute effects, such as reduced feed intake, reduced weight gain, and decreased reproductive performance as well as chronic effects such as liver damage and depression of the immune system [6]. In addition, metabolites of mycotoxins may be present in products of animal origin, especially in cattle, which metabolize aflatoxin B1 and excrete aflatoxin $\mathrm{M}$ in milk [7]. In humans, ingestion of mycotoxin products is associated with the development of several types of cancer, and both aflatoxin B1 and the metabolite aflatoxin M1 are considered to be substances with potential hepatocarcinogenicity [5].

Knowledge regarding the presence and identification of fungi and mycotoxins in silages is extremely important, especially because this raw material makes up a large part of the diet of ruminants, as silages are favorable for fungal growth and consequent contamination. Thus, the objective of this study was to evaluate the effect of compaction degree and particle size on the presence of mycotoxins and the bromatological composition of corn silages.

\section{MATERIAL AND METHODS}

Corn silage (whole plant) samples were collected from 47 silos of rural properties located at the northern region $\left(23^{\circ} 33^{\prime} 03^{\prime \prime} \mathrm{S}, 5^{\circ} 27^{\prime} 39^{\prime \prime W}\right)$ of Paraná State, Brazil. The Köppen climate classification for the region is $\mathrm{Cfb}$ [8], with an average temperature of $18.8^{\circ} \mathrm{C}$ and average annual rainfall of $1507 \mathrm{~mm}$.

The dimensions of the evaluated silos were between 25 and $50 \mathrm{~m}$ for length, 6 and $12 \mathrm{~m}$ for width, and 2 to $3.5 \mathrm{~m}$ for height. Silage confection was performed during January 2016, and the silos were kept closed until May 2016, when they were opened. The sample collection period was May to August 2016. The samples were collected at several points throughout each silo and at different depths. The edges and the material in contact with the floor or silage with mold or dirt were excluded. The amount of silage withdrawn per silo accounted for approximately $2 \mathrm{~kg}$ of fresh matter, which was packed in a plastic bag. Air from the bag was removed, and the bag was properly labeled and then transported to the bromatology laboratory in a Styrofoam box with ice.

Fresh samples from the same silage were homogenized in plastic containers, and 10-g aliquots were taken for $\mathrm{pH}$ measurement, according to the methods described by Cherney and Cherney (2003) [9], in which the samples were placed in a container with $100 \mathrm{~mL}$ of distilled water for 30 
$\mathrm{s}$, followed by homogenization of the mixture using a glass stick. The $\mathrm{pH}$ was measured immediately after the samples arrived at the laboratory (initial $\mathrm{pH}$ ) and again after $1 \mathrm{~h}$ (final $\mathrm{pH}$ ).

Silages were classified according to the amount of material ensiled and the size of the silo. They were grouped into two degrees of compaction: $600 \mathrm{~kg} \cdot \mathrm{m}^{-3}$ (22 corn silage samples) and $700 \mathrm{~kg} \cdot \mathrm{m}^{-3}$ (25 corn silage samples).

Particle size was assessed using the Penn State Particle Size Separator technique [10] adapted by Mari and Nussio (2002) [11]. For this purpose, $250 \mathrm{~g}$ of fresh silage from each sample was placed on the upper sieve $(38 \mathrm{~mm})$. Stirring was manually performed on a flat and smooth surface by vigorously shaking the sieves for five times in eight sets (after every five agitations, sieve set was rotated by $90^{\circ}$ ), totaling 40 movements. After shaking, the weight of the sample retained in each sieve was recorded, and the average size of 20 particles retained in the upper sieve was measured using a ruler. The samples were divided into two groups based on the mean particle size: one particle group with size smaller than the median (14.56 mm; 21 corn silage samples) and the other with size larger than the median (26 corn silage samples).

The concentrations of aflatoxin (AFLA B1, B2, G1, and G2), zearalenone (ZEA), deoxynivalenol (DON), and fumonisins (FB, fumonisin $\mathrm{B} 1$ and $\mathrm{B} 2$ ) were determined using the methods developed by Neogen (2019) [12]. For this, $10 \mathrm{~g}$ of each sample was diluted in $200 \mathrm{~mL}$ of distilled water. The samples were shaken and sequentially filtered, and mycotoxin detection was performed using an enzyme-linked immunosorbent assay with the Neogen kit (Veratox). A sample was considered positive when the contamination level was above the detection limit (DON, 100 $\mu \mathrm{g} . \mathrm{kg}^{-1}$; AFLA, $2.5 \mu \mathrm{g} \cdot \mathrm{kg}^{-1}$; ZEA, $5 \mu \mathrm{g} \cdot \mathrm{kg}^{-1}$; FB, $200 \mu \mathrm{g} \cdot \mathrm{kg}^{-1}$ ).

Dry matter $(\mathrm{DM})$ and mineral matter contents of the silages were determined according to the methodology described by AOAC (2000) [13]. Neutral detergent fiber, acid detergent fiber, ethereal extract, and crude protein fractions were obtained according to the methodologies described by Mizubuti et al. (2009) [14]. The estimation of the total digestible nutrient and digestible DM values were conducted using the equations described by Capelle et al. (2001) [15]. Ammoniacal nitrogen was determined using methods described by Mizubuti et al. (2009) [14].

Statistical analysis was carried out using the software STATA 16.0. The studied variables were analyzed according to the degree of compaction and particle size. A Shapiro-Wilk test was used to evaluate the normality of the residuals, and since they did not present a normal distribution, the variables were analyzed using a non-parametric Mann-Whitney $U$ test $(p<0.05)$ to compare the means between the groups.

\section{RESULTS}

The degree of compaction only affected the initial and final $\mathrm{pH}$ of the forage corn silage (Table 1). Silages with a medium compaction degree had higher initial and final $\mathrm{pH}$ values than silages with a high compaction degree $(\mathrm{p}<0.05)$. Particle size only affected the DM content of the silage. Silage with a mean particle size less than or equal to $14.56 \mathrm{~mm}$ had $12 \%$ higher $(\mathrm{p}<0.05) \mathrm{DM}$ content than silage with a mean particle size over $14.56 \mathrm{~mm}$. 
Table 1. Bromatological composition and fermentative parameters of forage corn silage according to compaction degree and mean particle size.

\begin{tabular}{|c|c|c|c|c|}
\hline \multirow[b]{2}{*}{ Variable $^{*}$} & \multicolumn{2}{|c|}{ Compaction degree } & \multicolumn{2}{|c|}{ Particle size } \\
\hline & $\begin{array}{c}\text { Medium } \\
\left(600 \mathrm{~kg} . \mathrm{m}^{-3}\right)\end{array}$ & $\begin{array}{c}\text { High } \\
\left(700 \mathrm{~kg} \cdot \mathrm{m}^{-3}\right)\end{array}$ & $\leq 14.56 \mathrm{~mm}$ & $>14.56 \mathrm{~mm}$ \\
\hline $\mathrm{DM}\left(\mathrm{g} \cdot \mathrm{kg}^{-1}\right)$ & 331.0 & 324.0 & $348.0^{\mathrm{a}}$ & $311.0^{\mathrm{b}}$ \\
\hline $\mathrm{MC}\left(\mathrm{g} \cdot \mathrm{kg}^{-1} \mathrm{DM}\right)$ & 34.9 & 37.5 & 31.6 & 36.6 \\
\hline $\mathrm{CP}\left(\mathrm{g} \cdot \mathrm{kg}^{-1} \mathrm{DM}\right)$ & 65.1 & 62.0 & 60.9 & 66.1 \\
\hline $\mathrm{EE}\left(\mathrm{g} \cdot \mathrm{kg}^{-1} \mathrm{DM}\right)$ & 15.4 & 15.7 & 16.0 & 14.8 \\
\hline NDF (g.kg-1 DM) & 473.0 & 463.4 & 463.0 & 481.0 \\
\hline $\mathrm{ADF}\left(\mathrm{g} \cdot \mathrm{kg}^{-1} \mathrm{DM}\right)$ & 277.0 & 261.3 & 262.0 & 268.0 \\
\hline $\mathrm{DDM}\left(\mathrm{g} \cdot \mathrm{kg}^{-1} \mathrm{DM}\right)$ & 668.0 & 671.0 & 671.0 & 665.0 \\
\hline TDN (g.kg-1 DM) & 702.0 & 706.0 & 706.0 & 699.0 \\
\hline Initial $\mathrm{pH}$ & $3.94^{\mathrm{a}}$ & $3.76^{\mathrm{b}}$ & 3.87 & 3.80 \\
\hline Final $\mathrm{pH}$ & $3.92^{\mathrm{a}}$ & $3.75^{\mathrm{b}}$ & 3.91 & 3.85 \\
\hline $\mathrm{AN}\left(\mathrm{g} \cdot \mathrm{kg}^{-1} \mathrm{TN}\right)$ & 29.5 & 33.5 & 30.9 & 31.3 \\
\hline
\end{tabular}

Data are presented as median. *DM: Dry matter; MC: Mineral content; CP: Crude protein; EE: Ethereal extract; NDF: Neutral detergent fiber; ADF: Acid detergent fiber; DDM: Digestible dry matter; TDN: Total digestible nutrient; AN: Amoniacal Nitrogen, TN: Total Nitrogen. Different letters denotes difference among compaction degree or particle size.

The evaluation of particle size proportion across all silages indicated a spread of sizes as follows: $14 \%$ of particles were larger than $19 \mathrm{~mm}, 50.7 \%$ of particles had sizes between 7.8 and $19 \mathrm{~mm}$, $33.4 \%$ of particles were between 4 and $7.8 \mathrm{~mm}$, and $1.9 \%$ of particles were smaller than $4 \mathrm{~mm}$.

There was no effect ( $p>0.05)$ of compaction degree or mean particle size on the concentration of mycotoxin in silage samples (Table 2). All silo samples analyzed had no contamination or had levels below the detection limit for fumonisin mycotoxin. Eighty-three percent of the silo samples had contamination above the detection limits with at least one of the other evaluated mycotoxins.

Table 2. Mycotoxins concentrations in forage corn silage according to compaction degree and mean particle size.

\begin{tabular}{|c|c|c|c|c|c|c|c|c|}
\hline \multirow{3}{*}{ Mycotoxin } & \multicolumn{4}{|c|}{ Compaction degree } & \multicolumn{4}{|c|}{ Particle size } \\
\hline & \multicolumn{2}{|c|}{$\begin{array}{l}\text { Medium (600 } \\
\text { kg.m-3) }\end{array}$} & \multicolumn{2}{|c|}{$\begin{array}{c}\text { High } \\
\left(700 \mathrm{~kg}^{-3} \mathrm{~m}^{-3}\right)\end{array}$} & \multicolumn{2}{|c|}{$\leq 14.56 \mathrm{~mm}$} & \multicolumn{2}{|c|}{$>14.56 \mathrm{~mm}$} \\
\hline & $\mathbf{N}$ & $\mathbf{M e}$ & $\mathbf{N}$ & Me & $\mathbf{N}$ & Me & $\mathbf{N}$ & Me \\
\hline Deoxynivalenol $\left(\mu \mathrm{g} . \mathrm{Kg}^{-1}\right)$ & $07 / 22$ & 306.8 & $10 / 25$ & 328.6 & $10 / 21$ & 328.6 & $07 / 26$ & 293.2 \\
\hline Aflatoxin $\left(\mu \mathrm{g} . \mathrm{Kg}^{-1}\right)$ & $09 / 22$ & 4.9 & $18 / 25$ & 8.6 & $11 / 21$ & 5.9 & $16 / 26$ & 8.7 \\
\hline Zearalenone $\left(\mu \mathrm{g} . \mathrm{Kg}^{-1}\right)$ & $10 / 22$ & 252.1 & $23 / 25$ & 348.5 & $13 / 21$ & 193.5 & $20 / 26$ & 323.0 \\
\hline
\end{tabular}

$\mathrm{N}=$ Number of positive samples/total; Me=Median.

\section{DISCUSSION}

Despite most samples being contaminated with mycotoxins, the nutritional value was similar among silages, which were within the observed standard values for forage corn silages in Brazil [16]. In this study, the compaction degree did not affect the nutrient composition of silages. Velho et al. (2007) [17] evaluated corn silages made in $30 \mathrm{~L}$ mini-silos with a compaction degree of 500 and $600 \mathrm{~kg} . \mathrm{m}^{-3}$. Similar to our study, their study demonstrated no significant differences in DM content ( $p>0.05$ ). However, the DM values determined in our study were higher (331 and $324 \mathrm{~g} . \mathrm{kg}^{-}$ ${ }^{1}$ for compaction degrees of $600 \mathrm{~kg} \cdot \mathrm{m}^{-3}$ and $700 \mathrm{~kg} \cdot \mathrm{m}^{-3}$, respectively) than the $28.7 \%$ value obtained by Velho et al. (2007) [17] for DM with similar compaction $\left(600 \mathrm{~kg} \cdot \mathrm{m}^{-3}\right)$. This difference was possibly due to differences in the ensiling process and the nutritional quality of the corn used, as Velho et al. (2007) [17] harvested corn and assessed silages in May, which was earlier than those in our study.

Samples with a lower mean particle size had higher DM content than samples with larger average particle size, as particle size influences air expulsion and consequently silage compaction, which 
may cause changes in the final DM content of the silage. According to Heinrichs and Jones (2016) [18], the ideal composition of particle size in forage corn silage should be as follows: $3 \%-8 \%$ of particles larger than $19 \mathrm{~mm}, 45 \%-65 \%$ of particles between 7.8 and $19 \mathrm{~mm}, 10 \%-30 \%$ of particles between 4 and $7.8 \mathrm{~mm}$, and less than $10 \%$ of particles smaller than $4 \mathrm{~mm}$. According to this classification, in the present study, $14 \%$ of particles were larger than $19 \mathrm{~mm}$, whereas the proportions of other particles were within or near the ideal proportion.

The median values obtained for the initial and final $\mathrm{pH}$ values were approximately $5 \%$ higher for silages with compaction degree of $600 \mathrm{~kg} \cdot \mathrm{m}^{-3}$ than those for silages with higher compaction degrees. $\mathrm{pH}$ can be influenced by silage compaction, with the highest $\mathrm{pH}$ values being obtained in low-compacted materials [19], similar to the results obtained in the present study. Although the $\mathrm{pH}$ of silages with different compaction degrees significantly differed, it is important to note that all observed $\mathrm{pH}$ values were lower than 6.0, which is related to a reduction in the development of fungi [1].

The median values obtained for the ammoniacal nitrogen variable in relation to the total nitrogen varied from 29.5 to $33.5 \mathrm{~g} . \mathrm{kg}^{-1}$ total nitrogen (TN), which are lower than the average values reported by Pinto et al. (2007) [20] and by Velho et al. (2007) [17] of 58 and $41 \mathrm{~g}^{\mathrm{kg}} \mathrm{kg}^{-1} \mathrm{TN}$, respectively, for corn silage and similar to those reported by Santos et al. (2010) [21], with a mean of $29 \mathrm{~g} \cdot \mathrm{kg}^{-1} \mathrm{TN}$. The ammoniacal nitrogen quantity varies in relation to the position in the feed-out face (core, lateral, and apical parts) of the silage and the ensiling procedure [22]. This variable is indicative of the degradation of protein in the fermentation phase of silage formation, which is one of the most important parameters for determining the quality of fermentation [21] and should be below $10 \%$ in quality silage [23]. Therefore, the results obtained for the ammoniacal nitrogen variable in the present study are indicative of the quality of the forage corn silage samples analyzed.

The compaction degree and particle size used in this study did not influence the presence of mycotoxins in the silages, with mycotoxins identified in all samples. However, the quantities of mycotoxins found were within the limits allowed by the European Union for maize-based foods for animal consumption [24, 25, 26]. Most of the samples evaluated presented the mycotoxins aflatoxin, zearalenone, and/or deoxynivalenol in the forage corn silages studied, demonstrating the importance of measures that control the development of mycotoxigenic fungi in forage corn silages.

The concentrations of DON and ZEA obtained in the present study were similar to those obtained by Schimidt et al. (2015) [27], 259 and $181 \mu \mathrm{g} \cdot \mathrm{kg}^{-1}$, respectively, when evaluating the mycotoxin concentration in corn silage from five Brazilian dairy-production regions. The same authors stated that the critical value for ZEA concentration for corn silage is $285 \mu \mathrm{g} \cdot \mathrm{kg}^{-1}$, which varies with several factors including the region, climate, and planting season [27]. The ZEA concentrations obtained in the present study are above this value, suggesting that environmental conditions of the places these silos were from are favorable for ZEA production.

\section{CONCLUSIONS}

Compaction degree did not influence the bromatological composition of corn silage. Additionally, the degree of compaction and particle size did not affect the presence of mycotoxins in corn silage. Corn silage produced in both compaction degree and particle size presented good mycotoxicological quality, did not presenting a toxicological risk to animals and human health.

\section{ACKNOWLEDGMENT}

This study was financed in part by the Coordenação de Aperfeiçoamento de Pessoal de Nível Superior - Brasil (CAPES) - Finance Code 001.

\section{REFERENCES}

1. Pereyra MLG, Alonso VA, Sager R, Morlaco MB, Magnoli CE, Astoreca AL, Rosa CAR, Chiacchiera SM, Dalcero AM, Cavaglieri LR. Fungi and selected mycotoxins from pre- and postfermented corn silage. J Appl Microbiol. 2008 Apr;104(4):1034-1041, doi:10.1111/j.1365-2672.2007.03634.x.

2. Muck RE. Factors influencing silage quality and their implications for management. J Dairy Sci. 1988 Nov;71(11):2992-3002, doi: 10.3168/jds.S0022-0302(88)79897-5. 
3. Ogunade IM, Martinez-Tuppia C, Queiroz OCM, Jiang Y, Drouin P,Wu F, Vyas D, Adesogan AT. Silage review: Mycotoxins in silage: Occurrence, effects, prevention, and mitigation. J Dairy Sci. 2018 May;101(5):4034-4059, doi: 10.3168/jds.2017-13788.

4. Fink-Gremmels J. The role of mycotoxins in the health and performance of dairy cows. Vet J. 2008 Apr;176(1):84-92, doi:10.1016/j.tvj1.2007.12.034.

5. IARC (International Agency for Research on Cancer). Some traditional herbal medicines, some mycotoxins, naphthalene and styrene. Lyon: IARC; 2002.

6. Golob P. On-farm mycotoxin control in food and feed grain [Online]. Good pratices for animal feed and livestock. FAO (2007). Available: http://www.fao.org/3/a-a1416e.pdf [15 July 2019]

7. Wang Q, Zhang Y, Zheng N, Guo L, Song X, Zhao S, Wang J. Biological system responses of dairy cows to Aflatoxin B1 exposure revealed with metabolomic changes in multiple biofluids. Toxins. 2019 Feb;11(2):77, doi:10.3390/toxins11020077.

8. Köppen W. Climatologia: con un estudio de los climas de la tierra. México: Fondo de Cultura Econômica; 1948.

9. Cherney JH, Cherney DJR. Assessing silage quality. In: Buxton et al. silage science and technology: Agronomy monograph No. 42. Madison: American Society of Agronomy; 2003.

10. Lammers BP, Buckmaster DR, Heinrinchs AJ. A simple method for the analysis of particle size of forage and total mixed rations. J Dairy Sci. 1996 May;79(5):922-928, doi: 10.3168/jds.S0022-0302(96)764421 .

11. Mari LJ, Nussio LG. O método Penn State Particle Size Separator para a predição do tamanho de partículas de silagens [Online]. Beefpoint (2002). Available: http://beefpoint.com.br/bn/radarestécnicos [15 October 2017]

12. Neogen, Veratox for Mycotoxins [Online] (2019). Available: http://foodsafety.neogen.com/en/veratox\#mycotoxins. [15 July 2019]

13. AOAC (Association of Chemical Analytical Chemystry), Official methods of analysis of AOAC international. 17 ed. Gaithersburg: AOAC; 2000.

14. Mizubuti IY, Pinto AP, Ramos BMO, Pereira ES. Métodos laboratoriais de avaliação de alimentos para animais. Londrina (Brazil): EDUEL; 2009.

15. Capelle ER, Valadares Filho SC, Silva JFC, Cecon PR. Estimates of the energy value from chemical characteristics of the feedstuffs. Rev Bras Zootec. 2001;30(6):1837-1856, doi:10.1590/S151635982001000700022.

16. Valadares Filho SC, Paulino PVR, Magalhães KA. (Eds). Exigências nutricionais de zebuínos e tabelas de composição de alimentos BR-Corte. Viçosa(Brazil): UFV; 2006.

17. Velho JP, Mühlbach PRF, Nörnberg JL, Velho IMPH, Genro TCM, Kessler JD. Chemical composition of maize silages with different packing densities. R Bras Zootec. 2007 Sep;36(5):1532-1538, doi:10.1590/S1516-35982007000700011.

18. Heinrichs J, Jones CM. Penn State Particle Separator [Online]. Penn State Extension (2016). Available: https://extension.psu.edu/penn-state-particle-separator [26 July 2019]

19. Senger CCD, Mühlbach PRF, Sánchez LMB, Netto DP, Lima LD. Chemical composition and 'in vitro' digestibility of maize silages with different maturities and packing densities. Cienc Rural 2005;35(6):1393-1399, doi:10.1590/S0103-84782005000600026.

20. Pinto AP, Mizubuti IY, Ribeiro ELA, Fey R, Palumbo GR, Alves TC. Ensilage evaluation of orange peel and corn silages in different storage times. Acta Sci Anim Sci. 2007;29(4):371-377, doi: 10.4025/actascianimsci.v29i4.995.

21. Santos RD, Pereira LGR, Neves ALA, Araújo GGL, Voltolini TV, Brandão LGN, Aragão ASL, Dórea, JRR. Fermentation parameters of silages of six maize varieties recommended for the Brazilian semi-arid region. Arq Bras Med Vet Zootec, 2010 Dec;62(6):1423-1429, doi: 10.1590/S010209352010000600019.

22. Gallo A, Bertuzzi T, Giuberti G, Moschini M, Bruschi S, Cerioli C, Masoero F. New assessment based on the use of principal factor analysis to investigate corn silage quality from nutritional traits, fermentation end products and mycotoxins. J Sci Food Agric. 2016 Jan;96(2):437-448, doi: 10.1002/jsfa.7109.

23. McDonald P, Henderson AR, Heron SJE. The Biochemistry of Silage, 2nd ed. Marlow: Chalcombe Publications; 1991.

24. EC, Commission Directive 2003/100/ EC of 31 October 2003 amending Annex I to Directive 2002/32/ EC of the European Parliament and of the Council on undesirable substances in animal feed [Online] (2003). Available: https://eur-lex.europa.eu /LexUriServ/LexUriServ.do?uri=OJ\%3AL\%3A2003\%3A28 5\%3A0033\%3A0037\%3AEN\%3APDF [20 May 2019].

25. EC, Commission recommendation of 17 August 2006 on the presence of deoxynivalenol, zearalenone, ochratoxin A, T-2 and HT-2 and fumonisins in products intended for animal feeding [Online] (2006). 
Available:

https://eur-

lex.europa.eu/LexUriServ/LexUriServ.do?uri=OJ:L:2006:229:0007:0009:EN:PDF [20 May 2019].

26. EC, Commission regulation (EC) No 386/2009 of 12 May 2009 amending Regulation (EC) No 1831/2003 of the European Parliament and of the Council as regards the establishment of a new functional group of feed [Online]

(2009)

Available: https://eurlex.europa.eu/LexUriServ/LexUriServ.do?uri=OJ:L:2009:118:0066:0066:EN:PDF [20 May 2019).

27. Schmidt P, Novinski CO, Junges D, Almeida R, Souza CM. Concentration of mycotoxins and chemical composition of corn silage: A farm survey using infrared thermography. J Dairy Sci. 2015 Sep;98(9):6609-6619, doi:10.3168/jds.2014-8617. 